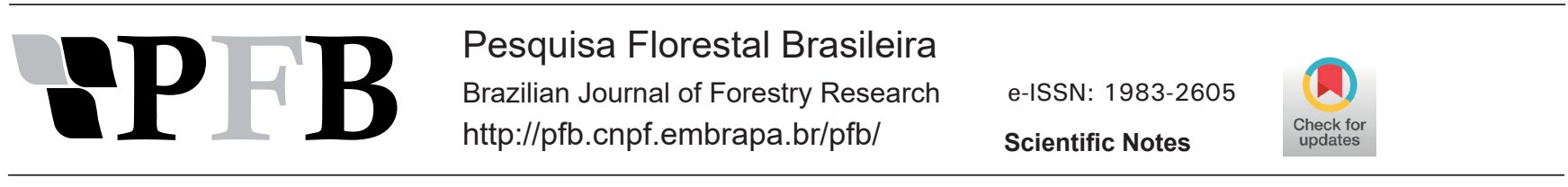

\title{
Mortality of Eucalyptus pilularis progenies and provenances after frost
}

\author{
Gabriel de Resende Baroni ${ }^{(i D}$, Otávio Camargo Campoe ${ }^{2}$ (D), Mário Dobner Júnior ${ }^{3}$ (D), Larissa Regina Topanotti ${ }^{(D)}$, \\ Paulo Henrique Muller da Silva ${ }^{1,4}$ (D) \\ ${ }^{1}$ Escola Superior de Agricultura "Luiz de Queiroz", Universidade de São Paulo, Avenida Pádua Dias, 11, C.P. 9, CEP 13418-900, Piracicaba, SP, Brazil \\ ¿Universidade Federal de Lavras, Departamento de Ciências Florestais, - Avenida Doutor Sylvio Menicucci, 1001 - Aquenta Sol, Lavras, MG, Brazil \\ ${ }^{3}$ Universidade Federal de Santa Catarina, Departamento de Agricultura, Biodiversidade e Florestas, Rodovia Ulysses Gaboardi, Km 3, Curitibanos, SC, Brazil \\ ${ }^{4}$ Instituto de Pesquisa e Estudos Florestais, Via Comendador Pedro Morganti, 3500, Bairro Monte Alegre, CEP 13415-000, Piracicaba, SP, Brazil
}

\section{"Corresponding author:}

gabrielbaroni92@gmail.com

Index terms:

Blackbutt

Cold tolerance

Thermal amplitude

Termos para indexação:

Amplitude térmica

Blackbutt

Tolerância ao frio

Received in $11 / 10 / 2019$

Accepted in 07/10/2021

Published in 10/12/2021
Resumo - We aimed to quantify frost tolerance and damage on Eucalyptus pilularis provenances and progenies in Curitibanos, Santa Catarina State, Brazil. Mortality and severity of damage were assessed before frost at 7 months old and at 14 and 19 months old after frost events. Frost resulted in plant mortalityof 55.7\%, with no difference among progenies and provenances. The tolerance of 5.3\% may have occurred due to specific local conditions (escape). We concluded that the species does not have tolerance to frost in subtropical environment, with daily thermal range from $-5^{\circ} \mathrm{C}$ to $28^{\circ} \mathrm{C}$.

\section{Mortalidade de progênies e procedências de Eucalyptus pilularis após geadas}

\begin{abstract}
O objetivo desse trabalho foi quantificar a tolerância e os danos causados por geadas em teste de procedências e progênies de Eucalyptus pilularis em Curitibanos, SC. A mortalidade e a severidade dos danos foram avaliadas antes das geadas ( 7 meses de idade) e após (14 e 19 meses de idade). As geadas causaram mortalidade de 55,7\% das plantas, sem diferença entre procedências e progênies. A tolerância de 5,3\% pode ter ocorrido apenas por condições locais específicas (escape). Conclui-se que a espécie não apresenta tolerância à geada em ambiente subtropical, com amplitudes térmicas diárias de $-5^{\circ} \mathrm{C}$ a $28^{\circ} \mathrm{C}$.
\end{abstract}

Frosts, considered harmful in the forest sector, occur when the average temperature is equal to or lower than $0{ }^{\circ} \mathrm{C}$ and cause damage to plant tissues, which may or may not form ice on leaf surfaces (De Melo-Abreu \& Ribeiro, 2010). The severity level of the damage is influenced by the magnitude of the minimum temperature; the duration of this temperature; the thermal amplitude; the physiological stage of the plant; and the microenvironment where plants are found (Sakai \& Larcher, 1987). In Brazil, frosts occur mainly in the South, and the phenomenon happens with high frequency in Santa Catarina State (Wrege et al., 2018). In the Midwest region of the state, frost occurs between May and September (Alvares et al., 2018), with 20 to 37 frost days per year, with intensity ranging from weak to medium, which equals grass temperature ranging from $0{ }^{\circ} \mathrm{C}$ to $-6{ }^{\circ} \mathrm{C}$.

Given the importance of the phenomenon in Santa Catarina, studies describing the effects and tolerance level of forest species to frost are essential, given the great damage caused by frost in this region (Higa et al., 1995, 2000). The information backed up by such studies 
can be used by forest producers and breeders to select the most suitable genotypes for regions with frost stress, as some locations in southern Brazil where the two most used eucalypt species cannot withstand frost (Assis et al., 2015; Silva et al., 2018, 2019;).

Such studies are required in Eucalyptus pilularis, because this specie has shown productive potential in some Brazilian regions (Pásztor, 1974; Souza et al., 1993) and its wood has potential for use in sawmills (Henson \& Smith, 2007), but there is a lack of studies on its adaptation to locations where frost occurs. However, there are reports in Australian regions that E. pilularis has low frost tolerance.

The reports cited by Henson \& Smith (2007) and Nichols et al. (2010) mentioned that E. pilularis planting in Australia is carried out in regions that show low frost frequency and that low relief areas should be avoided because of the probability of frost damage. However, this species is one of the subgenus Eucalyptus that occur in regions with frost. E. pilularis is native from regions coastal regions of Queensland and New South Wales states in Australia $\left(24^{\circ} \mathrm{S}\right.$ to $\left.37^{\circ} \mathrm{S}\right)$ with low to moderate frost incidence (Boland at al., 2006). We aimed to quantify the tolerance and damage caused by frost in progeny and provenance trial of E. pilularis under large daily thermal amplitude.

We harvested seeds of open-pollinated progenies in base populations for breeding. These populations are from the States of São Paulo and Minas Gerais (Table 1).
We produced the seedlings in Piracicaba, SP, located at Cwa climate, ie, subtropical with dry winters and hot and humid summers (Alvares et al., 2014). For the seedling production we used $55 \mathrm{~cm}^{3}$ tubes filled with organic substrate (pine bark, coconut fiber, rice husk and vermiculite). We performed fertigation twice a week with $12 \mathrm{~mm}$ of water supply. We set the fertigation solution up by: $450 \mathrm{~g}$ calcium nitrate; $300 \mathrm{~g}$ of ammonium nitrate; $250 \mathrm{~g}$ mono ammonium phosphate (MAP); $300 \mathrm{~g}$ of potassium nitrate; $250 \mathrm{~g}$ of magnesium sulfate; $250 \mathrm{~g}$ ammonium sulfate $2.5 \mathrm{~g}$ strained iron; $0.85 \mathrm{~g}$ manganese sulfate; $0.75 \mathrm{~g}$ of boric acid; $0.32 \mathrm{~g}$ zinc sulfate; 0.1 of copper sulfate and $0.005 \mathrm{~g}$ of sodium molybdate. All of these salts were diluted in 1,000 L of water.

After 90 days, we sent these seedlings to Curitibanos, $\mathrm{SC}$, where the climate is $\mathrm{Cfb}$, humid subtropical with mild summers and year-round rainfall (Alvares et al., 2014). In Curitibanos, the plow harrow attached to the tractor prepared the soil at $40 \mathrm{~cm}$ depth. We carried out the pre-planting ant control in full area by spreading formicide bait the basis of the active ingredient fipronil. Subsequently, we planted the seedlings using randomized block design: eight provenances; 104 progenies, three replicates, linear plots of five plants; spacing 3 x $1.5 \mathrm{~m}$. The planting procedure was carried out in October 2017. During this procedure, we irrigated each seedling using $2 \mathrm{~L}$ of water. We applied N-P-K 10-40-10 compost for basic fertilization according to soil analysis and it was applied formicide bait during the first year.

Table 1. Information about the sites of base populations of Eucalyptus pilularis mother trees.

\begin{tabular}{|c|c|c|c|c|c|c|}
\hline Provenance & Site & Institution & $\begin{array}{c}\text { Type of } \\
\text { population }\end{array}$ & $\begin{array}{c}\text { Plantation } \\
\text { year }\end{array}$ & Origin & $\begin{array}{c}\text { Number of } \\
\text { Progenies }\end{array}$ \\
\hline 7B 082 & Anhembi, SP & USP & SPA & 1982 & Multi-provenances & 9 \\
\hline 7C 103 & Anhembi, SP & USP & SPA & 1985 & Multi-provenances & 5 \\
\hline 7D 145 & Anhembi, SP & USP & $\mathrm{SO}$ & 1989 & Fraser Island, QLD & 12 \\
\hline 176 & Itamarandiba, $\mathrm{MG}$ & Aperam & SPA & 1984 & Beerburrum, QLD & 15 \\
\hline 498 & Itamarandiba, MG & Aperam & SPA & 1985 & $\begin{array}{c}\text { Conglomerate, Woolgoolga, NSW } \\
\text { Gallangowan, QLD Whian Whian, NSW }\end{array}$ & 15 \\
\hline 167 & Itamarandiba, MG & Aperam & SPA & 1984 & Bonga & 23 \\
\hline G5AK & Biritiba Mirim, SP & Suzano & Comercial & 1976 & Kiwarrak, NSW & 12 \\
\hline G5AC & Biritiba Mirim, SP & Suzano & Comercial & 1976 & Coopernook, NSW & 13 \\
\hline
\end{tabular}

$\mathrm{SPA}=$ seed production area; $\mathrm{SO}=$ seed orchard. More information in Silva et al. (2015) 
In the period prior to the occurrence of frost in April 2018, we evaluated the percentage of plant mortality and plant height. In addition, we installed an automated HOBO (Onset Computer Corporation, Bourne, MA, USA) average temperature data logger at the shelter location, $1.5 \mathrm{~m}$ above ground level, which recorded hourly temperature (in ${ }^{\circ} \mathrm{C}$ ). Thus, the average daily temperatures between April and November 2018 was calculated. At the end of data collection, we replaced average temperatures below $0{ }^{\circ} \mathrm{C}$ with $2{ }^{\circ} \mathrm{C}$. We performed this correction because in frost nights there is a difference between shelter and grass temperature (Geiger et al., 1995). The correction value was based on Silva \& Sentelhas (2001) who reported that in Campos Novos, near Curitibanos, there is a probability of $66.3 \%$ of this difference being between 0.1 and $4.0{ }^{\circ} \mathrm{C}$.

In December 2018, at 14 months after planting, we performed mortality and severity damage assessments. To assess the severity of damage, we grouped the plants into different classes according to the percentage of the aerial part affected by the damage: aerial part without damage; up to $25 \%$ of damaged aerial part; up to $50 \%$ with damage; up to $75 \%$ with damage. In addition, we attributed the plants that already had sprouts to a different class, regardless of the percentage of shoot damage. Finally, we performed an evaluation of plant height growth after the frost period in May 2019 at 19 months age.

To verify whether there was a difference between provenances and progenies in the mortality variable, we used the deviance analysis and the likelihood ratio test (LRT) using the Selegen software (Resende, 2002) with the December 2018 mortality data. Thus, we used the model 112, which is comprised of the vectors of the effects: repetition, progeny, origin, plot, and error. We considered the first effect as fixed and the others as random.

Minimum temperatures below $0{ }^{\circ} \mathrm{C}$ occurred between May and September (Figure 1). The temperature data logger recorded the first temperature of the shelter below $0{ }^{\circ} \mathrm{C}\left(-1.4^{\circ} \mathrm{C}\right)$ on May 21 and the last $\left(-0.5^{\circ} \mathrm{C}\right)$ on September 5. The lowest temperature in that period was $-6.8{ }^{\circ} \mathrm{C}$. Minimum temperature days below $0{ }^{\circ} \mathrm{C}$ lasted for 2 to 5 consecutive days. In those days, the daily temperature amplitude ranged from $17.0{ }^{\circ} \mathrm{C}$ to $32.9{ }^{\circ} \mathrm{C}$ and the average was $24.0^{\circ} \mathrm{C}$.

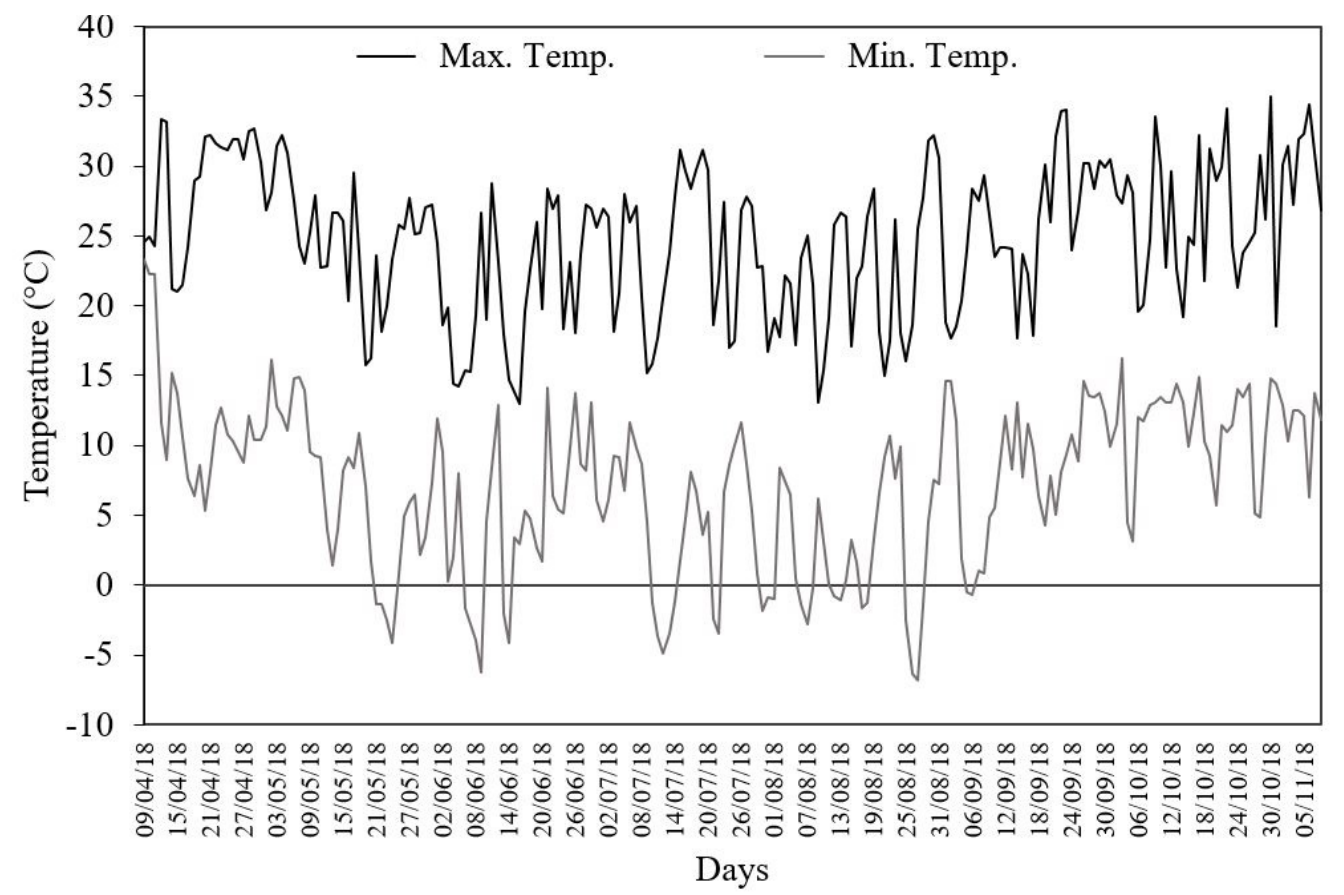

Figure 1. Maximum and minimum temperature during the study in Curitibanos, Santa Catarina State, Brazil. 
The period of frost occurrence, minimum temperatures and frost intensities in Curitibanos is in agreement with Wrege et al. (2018) and Alvares et al. (2018). Thus, we evaluated E. pilularis under periodic frost's that normally occur in the region.

The result demonstrated the low tolerance of $E$. pilularis to frost. One year after the first evaluation (May 2019) showed a 55.7\% increase in mortality rate (Table 1). The $14.8 \%$ of surviving plants presented a growth of $112.4 \mathrm{~cm}$ in height that occurred between the previous and subsequent season (after 12 months) to frost after summer 2018. When studying E. globulus Percentage in the Australian region where minimum temperatures of $-4.9^{\circ} \mathrm{C}$ occur after frost at 9 months of age, Thomson et al. (2001) observed $33.6 \%$ of mortality. Higa et al. (2000) reported that frost caused only $2.8 \%$ increase in mortality in E. dunnii in Campo Tenente, PR; however, this species is reported to be a tolerant to frost.

The number of tolerant plants was low (Table 2), even though these plants had a size that could provide greater tolerance to frost than seedlings recently implanted. During the beginning of the frost period, which occurred on May 2018, average height of plants was $94.5 \mathrm{~cm}$ at 7 months of age. It is important to highlight that larger plants have higher tolerance to frost and when the temperature gradually decrease until the first frost, this condition may provide more time to occur tree acclimation (Sakai \& Larcher, 1987).

The thermal amplitude presented a high average value $\left(24{ }^{\circ} \mathrm{C}\right)$ in the days of frost. In these days, the thermal amplitude were higher comparing to the winter days in which no frosts occurred. It should be noted that studies on the effects of frost have given little attention to daily thermal amplitude. However, the range is an important aspect that needs to be observed, as high daily fluctuations can contribute to the frost damage.

Henson \& Smith (2007) and Nichols et al. (2010) reported that E. pilularis can be planted in the Australian region of Morrows, where infrequent frosts occur. They also stressed that it is convenient to avoid lower slope positions where more severe frosts can occur causing plant mortality, therefore, the species can be planted where frosts with large daily thermal amplitudes do not occur. Nevertheless we do not recommend its cultivation where frost is a strong cold stress.

Table 1. Mortality and total height of Eucalyptus pilularis before and after frost in Curitibanos, Santa Catarina State, Brazil.

\begin{tabular}{|c|c|c|c|c|}
\hline Evaluation & Date & Age (months) & Mortality (\%) & $\begin{array}{l}\text { Total height } \\
\text { (cm) }\end{array}$ \\
\hline Before first period of frost & May/18 & 7 & 30.5 & 94.9 \\
\hline After first period of frost & $\mathrm{Dec} / 18$ & 14 & 85.0 & -- \\
\hline After second period of frost & May/19 & 19 & 86.2 & 207.3 \\
\hline
\end{tabular}

Table 2. Percentage of trees in blocks and the entire population by class of damage caused by 2018 frost on Eucalyptus pilularis in Curitibanos, Santa Catarina State, Brazil.

\begin{tabular}{ccccccc}
\hline Blocks & Without damage & up to $\mathbf{2 5 \%}$ & up to 50\% & up to $\mathbf{7 5 \%}$ & Sprouts (\%) & Mortality (\%) \\
\hline 1 & 1.5 & 3.9 & 4.2 & 2.5 & 19.4 & 68.5 \\
2 & 0.4 & 0.8 & 0.6 & 0.0 & 4.8 & 9.8 \\
3 & 0.4 & 0.2 & 1.0 & 0.2 & 0.9 & 9.8 \\
\hline
\end{tabular}


Considering the surviving plants, $9.8 \%$ showed faster recovery capacity (Table 3 ), showing sprouting at 3 months after the last frost event. The other surviving plants presented shoots at the last height evaluation (May 2019). Even so, E. pilularis can be considered of low recovery after frost, because few individuals could survive. Recovery capacity may be an evaluation criterion considered in the species breeding program (Higa et al., 2000) in the future use for cellulose and bioenergy. However, the same authors noted that for use in a sawmill, for lumber or saw wood, the effects of frost, even after recovery of the aerial part, cause tortuosity and bifurcation of the tree trunk leaving it with low-quality wood for this purpose.

Table 3. Deviance analysis and likelihood ratio test (LRT) for the effect of plot, progeny and provenance on plant mortality at 14 months of age, in Curitibanos, Santa Catarina State, Brazil.

\begin{tabular}{lll}
\hline Factor & Deviance & LRT (qui-square) \\
\hline Plots & -1797.82 & $57.05^{*}$ \\
Progeny & -1856.44 & $0.43^{\mathrm{ns}}$ \\
Provenance & -1854.87 & $2.00^{\mathrm{ns}}$ \\
Model & -1856.87 & \\
\hline
\end{tabular}

* and ns: significant and non-significant, respectively, at the $1 \%$ level of significance according to the tabulated chi-square of 6.63 .

Block 1 had lower mortality than the others (Table 2 ), thus there was a block effect. This difference was due to the effect of topographic variation since block 1 was located in the upper position of the slope; in the lower position, plants can be most damaged due to the concentration of cold air mass and the most drastic temperature reduction (Sakai \& Larcher, 1987). Through the LRT analysis for the mortality variable, we verified that there was a difference between plots and, consequently, there was heterogeneity within the same block (Table 3). Additionally to this observation, there was no difference between provenances and progenies, so there is no genotypic effect on plant survival capacity.

\section{Conclusions}

Eucalyptus pilularis is not suitable for planting in regions with frost with wide daily thermal range events, such as in Curitibanos, in Santa Catarina State, Brazil. The used seeds came from orchards and seeds production areas from São Paulo and Minas Gerais States, where climatic conditions is most suitable to the development of this species.

\section{Acknowledgements}

This study was financed in part by the Coordenação de Aperfeiçoamento de Pessoal de Nível Superior Brasil (CAPES) - "Finance Code 001". We sincerely thank the member companies and employees of the Forestry Research and Studies Institute (PCMF / IPEF) Cooperative Program on Forest Improvement; the employees and collaborators of the Universidade Federal de Santa Catarina, Campus Curitibanos, SC.

\section{References}

Alvares, C. A. et al. Köppen's climate classification map for Brazil. Meteorologische Zeitschrift, v. 22, n. 6, p. 711-728, 2014. https:// doi.org/10.1127/0941-2948/2013/0507.

Alvares, C. A. et al. Modeling monthly meteorological and agronomic frost days, based on minimum air temperature, in Center-Southern Brazil. Theoretical and Applied Climatology, v. 134, n. 1-2, p. 177-191, 2018. https://doi.org/10.1007/s00704-017-2267-6.

Assis T. F. et al. Melhoramento genético do eucalipto. In: Schumacher, M. V. \& Viera, M. (ed.). Silvicultura do eucalipto no Brasil. Santa Maria, RS: Ed. UFSM, 2015. p. 225-247.

Boland D. J. et al. Forest trees of Australia. 5 ed. Victoria: CSIRO Publishing, 2006. 736 p.

De Melo-Abreu, J. P. \& Ribeiro, A. C. Os danos de geada: conceitos, mecanismos e modelos de simulação. In: Figueiredo, T. de et al. Clima e recursos naturais: conferências de homenagem ao Prof. Doutor Dionísio Gonçalves. Bragança: Instituto Politécnico, 2010. p. $141-166$.

Geiger, R. et al. The climate near the ground. [S.1.]: Vieweg + Teubner Verlag, 1995.

Henson, M. \& Smith, H. J. Achievements in forest tree genetic improvement in Australia and New Zealand 1: Eucalyptus pilularis Smith tree improvement in Australia. Australian Forestry, v. 70, n. 1, p. 4-10, 2007. https://doi.org/10.1080/00049158.2007.10676255.

Higa, A. R. et al. Geadas: prejuízos a atividade florestal. Silvicultura, v. 16, n. 59 , p. $40-43,1995$.

Higa, R. C. V. et al . R. Resistência e resiliência a geadas em Eucalyptus dunnii Maiden plantados em Campo do Tenente, PR. Boletim de Pesquisa Florestal, n. 40, p. 57-56, 2000.

Nichols, J. D. et al. Subtropical eucalypt plantations in eastern Australia. Australian Forestry, v. 73, n. 1, p. 53-62, 2010. https:// doi.org/10.1080/00049158.2010.10676310. 
Pásztor, Y. P. C. Teste de procedências de Eucalyptus pilularis SM na região de Mogi Guaçu. IPEF, n. 8, p. 69-93, 1974.

Resende, M. D. V. de. Software SELEGEN - REML/BLUP. Colombo: Embrapa Florestas, 2002. 67 p. (Embrapa Florestas. Documentos, 77). https://www.infoteca.cnptia.embrapa.br/infoteca/ handle/doc/307175.

Sakai, A. \& Larcher, W. Frost survival of plants: responses and adaptation to freezing stress. [S.1.]: Springer Berlin Heidelberg, 1987.

Silva, J. G. de \& Sentelhas, P. C. Diferença de temperatura mínima do ar medida no abrigo e na relva e probabilidade de sua ocorrência em eventos de geada no Estado de Santa Catarina. Revista Brasileira de Agrometeorologia, v. 9, n. 1, p. 9-15, 2001.

Silva, P. H. M. et al. Selecting for stable and productive families of Eucalyptus urophylla S.T. Blake across a country wide range of climates in Brazil. Canadian Journal of Forest Research, v. 49, p. 87-95, 2018. https://doi.org/10.1139/cjfr-2018-0052.

Silva, P. H. M. et al. Selection of Eucalyptus grandis families across contrasting environmental conditions. Crop Breeding and Applied Biotechnology, v. 19, p. 47-54, 2019. https://doi.org/10.1590/198470332019v19n1a07.
Silva, P. H. M. et al. Use of genetic markers to build a new generation of Eucalyptus pilularis breeding population. Silvae Genetica , v. 64, p. 170-181, 2015. https://doi.org/10.1515/sg-2015-0016.

Souza, S. M. de et al. Variabilidade genética e interação genótipo x ambiente em Eucalyptus pilularis. Boletim de Pesquisa Florestal, n. 26, p. 3-16, 1993 .

Thomson, V. P. et al. Influence of previous frost damage on tree growth and insect herbivory of Eucalyptus globulus globulus. Austral Ecology, v. 26, n. 5, p. 489-499, 2001. https://doi. org/10.1046/j.1442-9993.2001.01144.x.

Wrege, M. S. et al. Risco de ocorrência de geada na região centro-sul do Brasil. Revista Brasileira de Climatologia, v. 22, p. 524-553, 2018. https://doi.org/10.5380/abclima.v22i0.57306. 